\title{
Negotiating Citizenship on Russian Makeover Television: Between Traditional and Neoliberal
}

\author{
Olga S. Kazakevich* \\ Siberian Federal University \\ 79 Svobodny, Krasnoyarsk, 660041, Russia
}

Received 04.05.2015, received in revised form 10.07.2015, accepted 26.08.2015

Having being introduced to the Russian audience in the early 2000s, beauty makeover television - a lifestyle TV with the focus on 'remaking' the participants' image, conduct and the self through the means of a wardrobe, makeup and hairstyle - has become widespread. Drawing from the concept of citizenship, this study uses data from the popular Russian makeover programs Modnyi Prigovor (Fashion Verdict) and Snimite Eto Nemedlenno! (Take It Off Immediately!) to examine the ways using which they transform women into ideal citizens by negotiating their relationships with and within public and private spheres. Via this examination, this study synthesizes two bodies of literature: citizenship studies and works on makeover TV. It is argued that on Russian makeover TV a specific type of citizen is suggested, created by two different yet connected discourses - (neo)traditionalist and neoliberal.

Keywords: makeover TV, lifestyle television, citizenship, neoliberalism, traditionalism, ideology, women, gender, class, Fashion Verdict, Take It Off Immediately.

DOI: 10.17516/1997-1370-2016-9-1-55-67.

Research area: culture studies.

\section{Introduction}

"This is definitely not the best choice for an adult Russian woman [rossiyanki]", comments the host of the famous Russian beauty makeover program Fashion Verdict (Modnyi Prigovor), whilst observing the participant's outfit. The question that arises is: what is? What is the best choice of clothes for an (adult) Russian woman and why? Which discourses influence the hosts' recommendations and how do they reflect the idea of 'good citizenship'? Throughout this study, I will be attempting to answer these questions by examining the discourse of popular Russian beauty makeover programs.
The term 'beauty makeover' refers to a particular type of lifestyle reality television that aims to 'remake' the participants - mostly women - in terms of their clothes, makeup, and taste, and hence to offer them a sort of cultural capital and, therefore, better chances in life. Style transformations happen with the help of fashion and stylist experts through dramatic comparisons of 'before' and 'after' body images. There are different ways of theorizing makeover television. Normally, it is conceptualized as part of the reality and lifestyle TV. Bratich (2007) makes an interesting observation by pointing out the changing nature of the relationship between

(C) Siberian Federal University. All rights reserved

* Corresponding author E-mail address: lola.kazakevich@gmail.com 
reality and its televisual representation. Now, he argues, reality television "may be less about representing reality than intervening in it... Less of an aesthetic genre than a set of techniques and social experiments..." (Bratich, 2007: 6-7). This kind of programming targets a female audience, with shows such as Fashion Verdict (Modnyi Prigovor) on Channel One, Take it Off Immediately! (Snimite eto nemedlenno!) on STS Channel, Cinderella. Restart (Zolushka. Perezagruzka) on TNT Channel, The Beauty Embassy (Posol'stvo Krasoty) on Yu Channel, and many others.

There is a vast amount of literature on the makeover genre that has become a cultural phenomenon. The perspectives through which Western makeovers are conceptualized are diverse and primarily concerned with the theories of self (Kubic \& Chory, 2007), identity (Wohlwend \& Medina, 2012) and body politics (Frith, Raisborough \& Klein, 2014; Gallagher and Pecot-Hebert, 2007), femininity (Marwick, 2010; Rodrigues, 2012), class (McRobbie, 2004), and capitalism (Redden, 2008). Furthermore, some of the studies have attempted to see makeover TV through the lens of citizenship and nation (Weber, 2009; Ouellette \& Hay, 2008; Rajagopalan, 2010). By examining the makeover television, Brenda Weber puts forward the idea of what she terms Makeover Nation - an imaginary terrain that promotes an ideal citizen: white, an active consumerist, willing to be engaged in the project of "American" citizenship (Weber, 2009, 39). She notes, though, that makeover programs do not necessarily need to be produced in the USA in order to convey a certain ideology of what it means to be a good subject/citizen. Whilst I find the concept of the Makeover Nation a fruitful and useful analytical tool to examine the makeover $\mathrm{TV}$ in connection with its symbolic effects, yet I think we need to trace the differences between, strictly speaking, national contexts. To name a few, class, gender, and power dynamics in the USA, Europe and Russia certainly differ. That is why it seems interesting and productive to trace the makeover logic of constructing the ideal citizen in a specific Russian context and, by doing so, to fill the gap in comprehending makeover (trans)national citizenship.

Even though makeover $\mathrm{TV}$ has become a valuable object for those engaged in cultural, media and gender studies in the West, little attention has been paid to those programs by Russian scholars. This phenomenon can be explained through the fact that in post-Soviet academia the tradition of critical analysis of cultural products - especially those perceived as "mass culture" ones - is not widespread and not seen as relevant and fruitful (Usmanova, 2001). My argument here is not that the Russian scholars refuse to deal with television products, but rather that even when makeover television manages to become either a center or periphery of research attention, it is mostly its linguistic and/or genre side, that interests Russian scholars (see Myasnikova, 2012). Meanwhile, in general, the Russian scholars show no intention to ascribe such programs in production of meanings and to look at how they operate in terms of power and ideology. Moreover, even when studying lifestyle programs, a common approach to dealing with reality TV involves no understanding of the complex issues underlying what at first glance appears to be 'light entertainment'. For instance, in her paper on the media content in the era of the specialized television programming, Myasnikova blames popular Russian TV programs, including Fashion Verdict, for refusing to deal with "global, ontological questions" (Myasnikova, 2012: 59). Instead, what they manage to achieve, Myasnikova argues, is "[to]carry the audience away from burning ideological issues by focusing on everyday life" (Myasnikova, 2012: 59). As one can see, by treating everyday life as something insignificant and not attention worthy, the scholar 
fail to grasp that everyday life is to large extent produced by and in different ways connected to ideology (see, for example, Althusser, 1971; Lefebvre, 1991; for critique on the perception of both television and everyday life as unproblematic, see Dahlgren, 1995: 40).

My argument is that on Russian makeover TV a model of the ideal female citizen is suggested, created by two different yet connected discourses - neotraditionalist and neoliberal. The ideal female citizen, thus, is a product of those two ideologies influencing Russian political and cultural landscape. Acquiring and polishing conventional feminine features in terms of appearance and conduct, thus reflecting (neo) traditional ideology, she also exemplifies and promotes her presence in the public sphere by featuring meaningful consumerism, social responsibility, maturity and professionalism, and, overall, the possibility of choice, which is a defining feature of neoliberalism.

Throughout the paper, I will be examining how citizenship is exercised drawing on a selected sample of makeover episodes. Firstly, I will be briefly describing a theoretical framework of this research. Secondly, the research questions will be formulated. Then, after listing and explaining the methods, I will conduct an analysis of the TV programs.

\section{Theoretical framework}

I conduct my research from a feminist perspective and base it on the intellectual tradition of cultural studies which is dealing with "the generation and circulation of meanings" (Fiske, 1996: 115). As it is widely recognized, culture, as well as its institutions (the media included) is ideological, meaning that it is a contested terrain where dominant groups - those in power - produce, in different cultural forms, their vision of society to the oppressed groups but the latter fight for their own meanings and interpretations. Ideology is no longer defined as 'false consciousness' but rather, as Althusser put it, as "the imaginary relationship of individuals to their real conditions of existence" (Althusser, 1971: 162). Given that "there is no practice except by and in an ideology" (Althusser, 1971: 170), in this paper, the presence of ideology in television discourse (which itself is the 'state ideological apparatus') is taken as a point of departure.

In an attempt to fill the gap in academic debates on makeover TV produced in Russia, this paper explores makeover programs through the concept of citizenship. Citizenship has been theorized through various perspectives, and it is established that the effects of citizenship include not only political, but also social and cultural implications. It is recognized that citizenship is a deeply gendered notion (Lister et al., 2007; Carver \& Mottier, 1998; Caldwell et al., 2009; Evans, 1993) that is also strongly connected with body issues. Women inevitably are seen in public space through their embodiment (Lister, 2003: 73), which to large extent both defines and prevents them as incapable of exercising citizenship. The juxtaposition of gendered citizenship discourse and the one of makeover, for both of which the body is prime concern, creates an interesting analytical perspective. Not only does the makeover transform the body, which is a "transformed social practice" (Connell, 1987: 83) itself, but it also reconfigures the whole set of associated practices, modes of conduct and attitudes, which, in turn, generate the discourse of citizenship.

\section{Research question}

Drawing on the concept of citizenship allows me to inscribe Russian makeover television into a specific social and political context. Thus, one of the central issues my project will seek to address is how, to what extent, and under which circumstances meanings produced in 
makeover programs reflect the current discourse on citizenship. The research question which I am attempting to answer is: What kind of citizen is produced on lifestyle Russian television and which ideologies contribute to the production of such citizen?

It seems important to note that we do not know what kind of real citizens the makeover shapes as there is no relevant data on how Russian audience perceives and reacts to these programs. Nevertheless, what we can conclude from Rajagopalan's (2010) study of Fashion Verdict, is that its online audience re-configures itself as a critical community that does not take the makeover messages and lessons for granted but, rather, views them critically. In doing so, she argues, the viewers exercise cultural citizenship, by which she means a mode of engagement "through which we lay stake to being part of a national-cultural collective and through which we articulate what it means to be part of that collective" (Rajagopalan, 2010: 100). Even though I find her observations highly valuable as it is often unclear to which extent viewers perceive what is suggested to them in the makeovers as a source of inspiration and/or contestation for their everyday life, still, for the purpose of this study, I don't view the makeover programs either in terms of what messages they convey nor in terms of how they are perceived by the audience. I do, however, try to identify which discourses influence the production of the makeover text as it is produced within specific modes of meaning about gender and class.

\section{Methods}

In my search for appropriate methodology for a critical inquiry into makeover TV, I have drawn upon the works on methodology in cultural studies (Storey, 1996). For the purposes of my analysis, I consider makeover programs I work with as cultural texts. I have chosen three episodes of each makeover program (Fashion Verdict: $16^{\text {th }}$ August, 2013, 15 ${ }^{\text {th }}$ November, 2013, $30^{\text {th }}$ January, 2014; Take it Off Immediately! $16^{\text {th }}$ June, 2013; 17 $7^{\text {th }}$ November, 2013; $12^{\text {th }}$ January, 2014) shown between January 2013 and January 2014. In performing textual analysis, I follow Johnson's (1996) notion of decentering the text. As he argues, "'the text' is no longer studied for its own sake, nor even for the social effects it may be thought to produce, but rather for the subjective or cultural forms which it realises and makes available" (Johnson, 1996: 97). The reason why we have to study the text is, according to the researcher, to find and analyze its ideological and other implications (he also lists "mode of address" and "subject position"). This is why I am particularly interested in uncovering ideologies hidden within makeover discourse, and this is why I consider the makeover text a perfect site from which to look at a citizenmaking process. In order to look at power and ideology more closely, I apply a critical discourse analysis (Fairclough, 1995). Furthermore, using the methods of rhetorical criticism with its focus on "how the verbal frames the visual in policyrelevant ways" (Hart and Daughton, 2005: 180) allows me to explore not only the narratives offered by makeover discourse but also the systems of values and ideology they appeal to.

In this study, I approach my chosen topic from a critical perspective as critique has been considered crucial for cultural studies from the very beginning (Johnson, 1996, 75). Nevertheless, the reason why I feel it is necessary to highlight this is because in post-Soviet academia the tradition of critical approaches in terms of identifying power relations in cultural products in the humanities in general and in so called culturology in particular has not been established and developed (Usmanova, 2001: 432-441) due to specific conditions in which the academic field was operating. Whilst there is the significant lack 
of research in Russian academia which would recognize how power relations are interwoven with and within cultural texts, I conduct my analysis using critical approaches, which means being critical of the existing social order as well as of academic approaches that do not take into account power relations and inequality (Weiss and Wodak, 2003: 39).

\section{Description}

Both programs based on which I draw my analysis, Take It Off Immediately! and Fashion Verdict, engaged in the process of transformation, that can be defined as "hanging the shape and appearance of one's outward self to reflect a socially constructed ideal of "attractiveness" (Gallagher and Pecot-Hebert, 2007, 64). Take It Off Immediately! has been aired since 2004 and is shown once a week on Sundays. The show is a copy of What Not To Wear - a program that appeared on BBC in the UK and then was adapted in the USA on TLC under the same name. Two hosts intervene in the life of the initially unwilling participant who is nominated by her friends to undergo a makeover. An allegedly homemade film made by the friends is shown at the beginning of each episode with the aim to provide the participant with the opportunity to look at herself through the others' eyes. After telling a story as to why she cannot handle her wardrobe and, thus, her life, in the way she is supposed to, the makeover participant, with the help of the hosts, gets rid of her old clothes while receiving some lessons on how to choose clothing appropriate for her age, social status, and body type. Then she goes shopping trying to implement these lessons, which, of course, she fails to do. The hosts come to give her a hand, and manage to do so by selecting a new wardrobe excellently. The final step in the makeover process is getting hair and makeup done. Now, when the transformation is complete, the participant presents her new self to the audience of her friends, relatives and also strangers who provide her an unbiased opinion.

Fashion Verdict, aired daily at 10:50 a.m. on Channel One, is now entering its ninth season with the ironic, double-bind slogan "To follow fashion is ridiculous, not to follow fashion is silly". Even though in general the makeover genre was borrowed by Russian television from Western $\mathrm{TV}$, Fashion Verdict stands as an example of the locally produced show that, however, lies within the makeover logic and imply the makeover conventions. The makeover process takes place in a setting vividly framed as a court. Three show hosts act as a judge, prosecutor, and lawyer while a participant finds herself in the dock accused of her bad unstylish appearance. It is a plaintiff who brings her to the show and tells the court why she needs a makeover. Then an investigation begins: the participant is asked to account for her questionable sartorial, makeup and hairstyle choices, which she does by telling a short story of her life. Then the protagonist and plaintiff go shopping together, the result of which the participant presents on the podium once they are done. Most of the times, these choices face a severe critique from the prosecutor (a stylish guru Evelina Khromchenko). Finally, stylists come into play and give a new look to the participant, which she presents on the podium, this time - to the audience's excitement.

\section{Analysis}

When Evelina Khromchenko, a prosecutor in Fashion Verdict, explains what is good and what is not for "an adult Russian woman [rossiyanki]" (Fashion Verdict, 30.01.2014), she does not refer to ethnicity (in which case she would rather use the word 'russkaya' to define a woman). What she does refer to, however, is citizenship: rossiyankaa woman who lives in Russia and defines herself as a Russian citizen. In order to maintain her status as a citizen of Russia, she needs to learn 
an appropriate way of presenting herself in terms of clothes, hairstyle and makeup, all of which would signal and support her status along the lines of gender, class, and age. In the next few paragraphs, I am exploring how those lines are articulated within the makeover discourse as well as how they contribute to the creation of a good citizen. Two conceptualizations of current social and political situation in Russia - (neo)traditional and neoliberal ones - are central to my research.

\section{Making It Neoliberal: Choice, Gaze, and Experts}

Intheirstudy of post-sovietpopulartelevision, Vassilieva and Bennett (2012) argues that, in spite of a common academics' belief, there has been no such thing as continuity between Soviet and post-Soviet tradition of popular culture. Rather, a "paradigm shift" has occurred when new formats and genres of popular culture and television were introduced to the Russian audience in the beginning of 1990s, signaling a break between the old and the new, as well as the mobilization of the latter for "the production of the capitalist subject" (Vassilieva and Bennett, 2012: 785). I am arguing that it has been of as much importance to produce the neoliberal subject in the beginning of 2000 s as it was to bring into the world the capitalist subject after the collapse of the USSR. The production of the neoliberal subject is a process to which makeover TV makes a significant contribution: "the impetus to facilitate, improve and makeover people's health, happiness and success through television programming is tied to distinctly 'neoliberal' reasoning about governance and social welfare" (Ouellette and Hay, 2008: 471).

Nadezhda Babkina, one of the hosts in Fashion Verdict, teaches a participant, 54-yearsold CEO: "You defend your wrong clothes while they are, you know, deeply provincial [provintcial'nye]. No status". A lesson on the importance of making correct choices goes in line with what is considered to be part of neoliberal ideology. In defining neoliberalism, I follow Ong (2006) in what she calls a technology of "rationalizing governing and self-governing" (Ong, 2006: 3). Furthermore, neoliberal ideology comes into being along with the emphasis on a "new ethic of the active, choosing, responsible, autonomous individual obliged to be free, and to live life as if it were an outcome of free choice" (Miller and Rose 2008: 18). The importance of individual rational choices finds its reflection in makeover logic like in the above mentioned example, in which, by interpreting the participant's choice of clothes, the host highlights the connection between individual choices and the position in the social hierarchy. By doing so, the program focuses on the individual responsibility to overcome the system limits rather than on the existence of such limits itself. Even social status can be seen as a choice contingent upon one's ability to frame oneself appropriately in terms of clothes, hairstyle and makeup. Hence, the Russian makeover does what Western makeovers always do: rearticulates "a potential lack of socioeconomic capital as merely the participants' lack of knowledge and expertise to dress themselves appropriately" (Gibbings and Taylor, 2010: 38).

There is a number of research on neoliberalism in post-Soviet Russia (Glinavos, 2010; Collier, 2011). The definitions and features of neoliberal conditions in post-soviet context are still under debate and some contradictions have been brought into light. For example, even though Vladimir Putin himself is seen as neither a liberal nor a neoliberal figure, it is argued that "his government adhered to important elements of what is usually considered the neoliberal recipe for reform" (Collier, 2011: 161). In her analysis of what she calls "Soviet-style neoliberalism", Hemment (2009) argues that different cultural forms, which remind of the Soviet era, are brought back to life by Putin's policies while finding new 
ways of defining and experiencing citizenship is what the state is primarily concerned with (Hemment, 2009: 48). Being aware of all the complications involved, I still view neoliberal ideology as an important factor in the Russian current social, political, and cultural landscape.

The importance of both making the correct choices and - no less important - being able to enjoy the results underlies the makeover discourse on Russian TV. A highly recommended choice to make is the choice to be looked at. Sharing impressions from a participant's new look, the Take It Off Immediately! hosts comment, "Trendy. Stylish. One would want to scrutinize her". Later in the same episode, they once again stress, "You are shining, and it is such a pleasure to look at you". In another episode, after the transformation happened, they conclude: "People will turn around [oborachivat'sya] to look at you". The strong (although hardly articulated) emphasis on women's willingness as well as responsibility to exemplify what Malvey calls "looked-at-ness" (Mulvey, 1975) and, by doing so, to satisfy the gaze that can be traced here. The gaze, though, is not necessarily the male gaze, as one would have expected. Rather, it is a gaze of middle class public (Gibbings \& Taylor, 2010: 34). What is also interesting is that gaze is no longer seen as "objectifying but as a tool of empowerment" (Weber, 2009: 82), one that can be enjoyed and from which a pleasure can be derived. "Everyone adores you! Do you enjoy it?", a participant is asked by the hosts of Take It Off Immediately. Her answer is yes.

Another feature of Russian makeovers, reflecting neoliberal ideology, is the role which experts play. Fashion, hair, and style gurus have a profound influence on those who strive to fit in the current cultural context. In Fashion Verdict, an invited celebrity calls a participant to leave her attempts to improve herself and, instead, to accept what the experts suggest: "Lena, be an expert in your [professional] field. Here we have experts in what you really need in order to change, grow, move on, and, most importantly, to be a woman". To some extent, it is not so much about participants' self-management as it is about reasonable outsourcing: since there are people trained specifically to help ordinary people with choices concerning their appearance, one should (or even must) surrender into the hands of those experts. Interestingly, their work is regarded as highly professional and difficult, in other words, as something which ordinary, untrained people would not cope with. For example, Julia, a 22-years-old deviant dresser wearing only white and black, confesses to the camera, "[It] turns out, it is not so simple to choose the clothes, especially colorful ones. It requires knowledge. It is mastery". Furthermore, the process of changing takes work - not only for the participant but also for the experts. "Stop crying, let's work" - that is how the hosts of Take It Off Immediately see their job when they are about to look at the participant's wardrobe. As Rose (1998) puts it,

"The guidance of selves is no longer dependent on the authority of religion or traditional morality: it has been allocated to 'experts of subjectivity' who transfigure existential questions about the purpose of life and the meaning of suffering into technical questions of the most effective ways of managing malfunction and improving "quality of life"' (Rose, 1998: 151).

It is also worth noting that whenever the term "professionalism" appears on the programs, chances are it refers to the professionalism of style experts, not the participant'. The implication here being is that the work of improving one's image requires special knowledge that can be acquired 
through training, learning, and experience. Undergoing a self-makeover is neither a joke nor a caprice. It is, rather, our obligation as citizens to make ourselves better with the help of experts, and, through this, to manifest our social responsibility and conformity. What seems interesting is that in order to become a participant, a person needs to be what Winslow terms "reconfigured as a subjectin-crisis" (Winslow, 2012: 303). That is, whatever the person's initial circumstances are, in order to achieve the makeover's goal they are portrayed as being in crisis. The crisis serves as an entry point into the problem-solving makeover discourse. Learning to cope with difficult circumstances, no matter how difficult they are, through the means of makeover and style lessons it provides is one of the main lessons of such programs. In addition, this strengthens the neoliberal component of the show by reinforcing the role of experts: it is style experts whom the further life of the participant depends on since they possess unique knowledge about overcoming the crisis and achieving a new, better life.

\section{Keeping It Traditional: Weakness and Men}

As my analysis shows, the techniques by which citizens are supervised on Russian makeover TV are rooted in the neoliberal ideology rather than in what can be called Russian "traditional values". Yet, the way the makeovers frame the participants' stories one might call very patriarchal-oriented. For example, the prosecutor and fashion guru Evelina Khromchenko in Fashion Verdict approves the participant's "Afterbody" (Weber, 2009) by saying, "You exemplify the beautiful pure woman's essence, young but adult at the same time, and also undressed, meaning that a man would have something to do for the rest of his life". In another Fashion Verdict episode, Evelina Khromchenko describes the clothes of Natasha, a 35-years old mother-of- two: "What I miss in these outfits is a dress. I miss something feminine, something that makes you cute, vulnerable, desirable, and in need of protection". Even though Natasha is a strong, independent woman, still the makeover suggests that she has to appear weak in order to attract a man and find happiness.

These two examples are not to suggest that this kind of implication is unique and only appears on Russian makeovers. In fact, the Western ones also rely upon conventional femininity (Weber, 2009: 128). However, despite the fact that a specific form of logic is shared by all makeover programs, there are, of course, some specificities in navigating the subjects of transformation within the realm of a given social and cultural context. In case of Russia, it is a combination of the traditionalist rhetoric and the one of development and progress (Muravyova, 2014) that defines how the makeover views and understands women. It is the conjunction of both that underlies the makeover discourse.

Both the traditional and 'progressive' narratives are termed differently by scholars. Rendering their debates around the concept of gendered citizenship, Russian scholars Temkina and Zdravomyslova (2003) argue that the core ideology which gender citizenship is based on is neotraditionalism (Zdravomyslova \& Temkina, 2003: 142). They use the concept of gender citizenship as an analytical tool to examine gender order in contemporary Russia. In their study, Soviet and post-Soviet gender citizenship is defined as "ideology and politics that both define citizens' duties and responsibilities, as well as their social practices, on the basis of their sex, and generate and regenerate gender inequality" (Zdravomyslova \& Temkina, 2003: 141). Whereas Temkina and Zdravomyslova see neoliberal connotations as part of neotraditional rhetoric, I, however, classify them into a specific 
category as they bring their own agenda and connotations.

Another way of theorizing traditional and 'progressive' ideologies accounting for the makeover texts is suggested by Vera Zvereva (2010) in her study of Russian lifestyle TV. She argues that the makeover programs "invite viewers to explore the identity of a "European" citizen or a citizen of the global world" (Zvereva, 2010: 275) in an attempt to overcome their very Soviet-like ways of life (e.g., mostly in terms of the style of the houses but also the personal appearance). As my analysis reveals, indeed, the Soviet-style outfits either occasionally chosen or worn at all the times by the participants, are seen as forbidden and are in fact ridiculed (e.g., in Take It Off Immediately! 34-years-old Oksana gets an absolute 'no' from the hosts for a chosen dress wearing which she looks like "a Soviet woman"). It seems to be related to the bad memories associated with the Soviet era in terms of poor choice available to ordinary people and poor taste (Lebina, 2014). Furthermore, Soviet influences on the Russian TV attract research attention time and again: for example, it has been established that cultural patterns that frame Fashion Verdict are rooted in Russian as well as in Soviet cultural narratives such as "Psychotherapy Session (Beseda s Psikhologom), Comrades' Court (Tovarishcheskii Sud), Kitchen Talks (Kukhonnye Razgovory), and Fashion Show (Pokaz Mod)" (Lerner \& Zbenovich, 2013).

Traditions, to which traditionalist discourse refers, thus, can be found in the Soviet past, although reconfigured and rethought. In essence, this analysis confirms what is termed as a Soviet 'gender contract of working mother' (Temkina and Rotkirch, 2002), which means that woman is primarily concerned with her duties as mother and wife but she also has to participate in labor market as she needs to financially contribute to the family's well-being.

\section{Conclusion}

The collapse of the USSR and the establishment of the new mode of media culture in the post-Soviet context influence the ways in which contemporary Russian television adopts and creates formats and genres. Makeover TV, having being introduced to the Russian audience in 2000 s, can be seen as a reflection of traditional and neoliberal reasoning in the current social and political discourse. As my analysis has shown, these two main discourses are mobilized on makeover programs: interwoven, they create a complex set of meanings. As the very nature of makeover TV and its constant willingness to improve people's life is strongly connected to neoliberal ideology, Russian makeover programs follow the same path as the Western ones, by focusing on 'correct' choices in terms of one's appearance and conduct as a means of empowerment. From this perspective, women's participation in a public sphere is encouraged, be it labour market or consumption. Furthermore, the former as well as the latter serves as a means of empowerment because its main goal seems to be to confirm that a participant is a good citizen: she knows how to consume well and how to handle unfortunate circumstances without complaints, merely through appropriate clothing. Another finding of this study is the significant role of experts in a makeover and, hence, life endeavor. As I argue, by stressing the tremendous importance of style professionals the makeover text in fact implies that the participant herself would never manage to change herself and, by so doing, it represents the significance of this event in one's life. What I call here "reasonable outsourcing" is the makeover's interpretation of the neoliberal thought in which "experts of subjectivity" (Rose, 1998) are considered powerful gurus of our times.

On the other hand, (neo)traditionalist ideology accounts for the emphasis a domestic 
sphere of women's life receives through constant focus on women's prime role as wives (or wivesto be). As this study reveals, the appeal to the supposedly 'pure' woman's "essence" as well as the articulation of women's weakness and dependence on men is the feature of Russian makeover TV. Soviet traditions and gender contracts are taken in hand and rearticulated in light of new set of meanings and subject positions available.

My concern in this paper was with what kind of the good citizen is promoted by the makeover cultural narratives. It appears that, within the makeover, the whole set of practices, action, and discourses helps to create a woman with new improved and updated features who is now able to perform her social, cultural, political and gender duties better. I argue that, at the end of each show, we have an improved version or rather a subject position - of a person who, after the makeover endeavor, is able to dress and behave appropriately, who belongs in current social and cultural context, and, finally, who is comfortable being under constant internal and external surveillance and, moreover, is able to enjoy it. Thus, the analysis of the makeover text through the citizenship framework contributes to the understanding of Russian makeover discourse in its relation to the broad range of current social, political and cultural debates.

\section{References}

Althusser, L. Ideology and Ideological State Apparatuses (Notes Towards an Investigation). Lenin and Philosophy, New York, Monthly Review Press, 1971, pp. 127-186.

Bratich, J. Z. Programming Reality: Control Societies, New Subjects and the Powers of Transformation. Makeover television: Realities remodelled, London and New York, I.B. Tauris, 2007, pp. 6-22.

Caldwell, K. L., Coll, K., Fisher, T., Ramirez, R.K., Siu, L. Gendered citizenships: transnational perspectives on knowledge production, political activism, and culture. Palgrave Macmillan, 2009, 225 p.

Carver, T., \& Mottier, V. Politics of sexuality: Identity, gender, citizenship. Vol. 4. London and New York, Routledge, 1998, 200 p.

Collier, S. J. Post-Soviet Social: neoliberalism, social modernity, biopolitics. Princeton and London, Princeton University Press, 2011, 304 p.

Connell, R.W. Gender and Power: Society, the Person and Sexual Politics. Polity Press, 1987, 334 p.

Dahlgren, P. Television and the public sphere: Citizenship, democracy and the media. Vol. 10. Sage Publ., 1995, 176 p.

Evans, D. Sexual citizenship: The material construction of sexualities. London and New York, Routledge, 1993, 351 p.

Fairclough, N. Critical discourse analysis: The critical study of language. London and New York, Longman, 1995, $265 \mathrm{p}$.

Fiske, J. British cultural studies and television. What is Cultural Studies? Arnold, 1996, pp. 115146.

Frith, H., Raisborough, J. \& Klein ,O. (2014). Shame and Pride in How to Look Good Naked. Feminist Media Studies, 14(2), 165-177.

Gallagher, A. H., \& Pecot-Hebert, L. (2007). You Need a Makeover!: The Social Construction of Female Body Image in "A Makeover Story", "What Not to Wear", and "Extreme Makeover". Popular Communication, 5(1), 57-79. 
Gibbings, S. \& Taylor J. (2010). From Rags to Riches, the Policing of Fashion and Identity: Governmentality and "What Not To Wear". vis-à-vis: Explorations in Anthropology, 10(1), 31-47.

Glinavos, I. Neoliberalism and the Law in Post Communist Transition: The Evolving Role of Law in Russia's Transition to Capitalism. London and New York, Routledge, 2010, 215 p.

Hart, R. P. \& Daughton, S. M. Modern rhetorical criticism, $3^{\text {rd }}$ ed. Pearson, 2005, 375 p.

Hemment, J. (2009). Soviet-style neoliberalism? Nashi, youth voluntarism, and the restructuring of social welfare in Russia. Problems of Post-Communism, 56(6), 36-51.

Johnson, R. What is cultural studies anyway? What is Cultural Studies? Arnold, 1996, pp. 75114.

Kubic, K.\& Chory, R. (2007). Exposure to Television Makeover Programs and Perceptions of Self. Communication Research Reports, 24(4), 283-291.

Lebina, N. Muzhchina i zhenschina: telo, moda, kul'tura. SSSR - ottepel'. [Man and woman: the body, fashion, and culture. USSR - ottepel']. Moscow, Novoe literaturnoye obozrenie, 2014, 208 p.

Lefebvre, H. Critique of Everyday Life, vol. 1. London and New York, Verso, 1991, 283 p.

Lerner, J. \& Zbenovich, C. (2013). Adapting the Therapeutic Discourse to Post-Soviet Media Culture: The Case of Modnyi Prigovor. Slavic Review, 72(4), 828-849.

Lister, R. Citizenship: Feminist Perspectives, $2^{\text {nd }}$ ed. Palgrave Macmillan, 2003, 323 p.

Lister, R., Williams, F., Anttonen, A., Bussemaker, J., Gerhard, U., Heinen, J., and Johansson, S. et al. Gendering Citizenship in Western Europe: New Challenges for Citizenship Research in a Crossnational Context. Bristol, Policy Press, 2007, 210 p.

McRobbie, A. (2004). Notes on 'What Not To Wear' and post-feminist symbolic violence. The Sociological Review, 52(s2), 97-109.

Mulvey, L. (1975). Visual pleasure and narrative cinema. Screen, 16 (3), 6-18.

Marwick, A. (2010). There's a Beautiful Girl Under All of This: Performing Hegemonic Femininity in Reality Television. Critical Studies in Media Communication, 27(3), 251-266.

Miller, P. \& Rose, N. Governing the Present. Administering Economic, Social and Personal Life. Cambridge, Polity Press, 2008, 246 p.

Murav'yova, M. (2014). Traditcionnye tcennosti i sovremennye sem'i: pravovye podchody $\mathrm{k}$ traditcii i modernu v sovremennoi Rossii [Traditional values and modern families: approaching the tradition and modernity from the law perspective]. Zhurnal issledovaniy sotcial'noi politiki, 12(4:4), 625-640.

Myasnikova, M. (2012). Problema kontenta v usloviyah spetcializatcii televisionnogo veschaniya (zhanrovyi aspect) [The problem of content and the TV content specialization (the problem of a genre)]. Izvestiya Ural'skogo federal'nogo universiteta, seriya 1: Problemy obrazovaniya, nauki i kul'turi, 4(107), 57-65.

Ong, A. Neoliberalism as exception: Mutations in citizenship and sovereignty. Duke University Press, 2006, 294 p.

Ouellette, L. \& Hay, J. (2008). Makeover television, governmentality and the good citizen. Continuum: Journal of Media \& Cultural Studies, 22(4), 471-484.

Rajagopalan, S. (2010). How to be a Well-groomed Russian: Cultural Citizenship in the Television/ New Media Interface. Digital Icons: Studies in Russian, Eurasian and Central European New Media, (3), 87-101. 
Redden, G. (2008). Economy and reflexivity in makeover television. Continuum. Journal of Media \&Cultural Studies, 22(4), 485-494.

Rodrigues, S. (2012). Undressing Homogeneity: Prescribing Femininity and the Transformation of Self-Esteem in How to Look Good Naked. Journal of Popular Film and Television, 40(1), $42-51$.

Rose, N. Inventing our selves: Psychology, power, and personhood. Cambridge University Press, $1998,222 \mathrm{p}$.

Storey, J. What is Cultural Studies? Arnold, 1996, 397 p.

Temkina, A. \& Rotkirch, A. (2002). Sovetskie gendernie kontrakty i ich transformatcii v sovremennoi Rossii [Soviet gender contracts and their transformations in contemporary Russia]. Sotciologicheskie Issledovania, 11, 4-14.

Usmanova, A. Gender i kul'tura v paradigme kul'turnych issledovaniy [Gender and culture in cultural studies]. Vvedenie v gendernye issledovaniya. S.Pt., Aleteiya, 2001, 427-464.

Vassilieva, J. \& Bennett, D. N. (2012). Mass culture and the production of the capitalist subject in post-communist Russia. Continuum, 26(5), 783-797.

Weber, B. Makeover TV: Selfhood, Citizenship, and Celebrity. Durham and London, Duke University Press, 2009, 318 p.

Weiss, G. \& Wodak, R. Introduction: Theory, Interdisciplinarity and Critical Discourse Analysis. Critical Discourse Analysis: Theory and Interdisciplinarity. Palgrave Macmillan, 2003, pp. 1-32.

Winslow, L. (2012). Colonizing Caster Semenya: gender transformation and the makeover genre. Western Journal of Communication, 76(3), 298-313.

Wohlwend, K. E., \& Medina, C. L. (2012). Media as nexus of practice: remaking identities in What Not to Wear. Discourse: Studies in the cultural politics of education, 33(4), 545-560.

Zdravomyslova, E. \& Temkina, A. Transformatciya gendernogo grazhdanstva v sovremennoi Rossii [The transformation of gendered citizenship in contemporary Russia]. Kuda prishla Rossiya, 2003, pp. 140-150.

Zvereva, V. (2010). Lifestyle Programs on Russian Television. Russian Journal of Communication, $3(3-4), 265-279$. 


\title{
Осмысление гражданства
}

\section{на российском телевидении преображения: \\ между традиционализмом и неолиберализмом}

О.С. Казакевич

Сибирский федеральный университет Россия, 660041, Красноярск, пр. Свободный, 79

\begin{abstract}
Представленные российской телевизионной аудитории в начале 2000-х шоу преображения - так называемое телевидение стиля жизни, фокусирующееся на переделке внешности u поведения участнии посредством одежды, макияжа и прически, - получили большое распространение и популярность. В этой статье материал популярных российских телевизионных шоу преображения «Модный приговор» $и$ «Снимите это немедленно!» анализируется в свете конщепиии гражданства, для того чтобы увидеть способы, которыми эти телевизионные форматы трансформируют женщин в идеальных граждан(ок), переосмысляя их отношения с публичным и приватным. Автор делает вывод о том, что на российском телевидении преображения создается специфический тип граждан, обусловленный влиянием двух различных, но взаимосвязанных дискурсов - (нео) традиционалистским и неолиберальным.
\end{abstract}

Ключевые слова: телевидение преображения, телевидение стиля жизни, гражданство, неолиберализм, традиционализм, идеология, женщина, гендер, класс, «Модный приговор», «Снимите это немедленно!».

Научная специальность: 24.00.00 - культурология. 